J. Dairy Sci. 98:6423-6432

http://dx.doi.org/10.3168/jds.2015-9512

(C) American Dairy Science Association ${ }^{\circledR}, 2015$.

\title{
Effects of direct-fed Bacillus pumilus 8G-134 on feed intake, milk yield, milk composition, feed conversion, and health condition of pre- and postpartum Holstein cows
}

\author{
S. Luan, ${ }^{*}$ M. Duersteler, † E. A. Galbraith, $†$ and F. C. Cardoso*1 \\ *Department of Animal Sciences, University of Illinois, Urbana 61801 \\ †DuPont Nutrition and Health, Waukesha, WI 53186
}

\section{ABSTRACT}

The usage of direct-fed microbials (DFM) has become common in the dairy industry, but questions regarding choice of strain, mode of action, and efficacy remain prevalent. The objective of this study was to evaluate the effects of a DFM (Bacillus pumilus 8G-134) on preand postpartum performance and incidence of subclinical ketosis in early lactation. Forty-three multiparous Holstein cows were assigned to 2 treatments in a randomized complete block design; cows in the direct-fed microbial treatment $(\mathrm{DFMt}, \mathrm{n}=21)$ received $5.0 \times 10^{9}$ $\mathrm{cfu} / \mathrm{cow}$ of $B$. pumilus in $28 \mathrm{~g}$ of a maltodextrin carrier, whereas cows in the control treatment $(\mathrm{CON}, \mathrm{n}=22)$ received $28 \mathrm{~g}$ of maltodextrin carrier alone. Treatments were top-dressed on the total mixed ration daily. Treatments were applied from $21 \mathrm{~d}$ before expected calving date to $154 \mathrm{~d}$ after calving. Cows on treatment DFMt tended to have lower serum haptoglobin concentration than CON cows on $\mathrm{d} 14$. Cows on treatment DFMt had higher IgA concentrations in milk than CON cows during the first week after calving. Cows fed DFMt had higher yields of milk, fat-corrected milk, energycorrected milk, milk fat, and milk protein during the second week of lactation than CON; however, we found no differences between treatments on milk yield and milk components overall. Cows on DFMt tended to have higher feed conversion and to have lower prevalence of subclinical ketosis (beta-hydroxybutyrate $>1.2$ $\mathrm{mmol} / \mathrm{L}$ ) on d 5 than cows fed CON. Dry matter intake, body weight, and body condition score were not affected by DFMt supplementation. Milk production efficiencies (calculated based on fat-corrected milk and energy-corrected milk) were higher by $0.1 \mathrm{~kg}$ of milk per kilogram of dry matter intake in cows that received DFMt compared with cows that received CON. In conclusion, cows receiving DFMt tended to have lower

Received February 26, 2015.

Accepted May 11, 2015.

${ }^{1}$ Corresponding author: cardoso2@illinois.edu incidence of subclinical ketosis than cows receiving CON. Cows fed DFMt tended to have higher feed conversion and evidence for greater immunity than CON. Supplementation with B pumilus 8G-134 may provide benefits for transition cow health and milk production efficiency.

Key words: direct-fed microbial, Bacillus pumilus, transition period, feed conversion

\section{INTRODUCTION}

Direct-fed microbials (DFM) have been studied to manipulate the microbial ecosystem and fermentation characteristics in the rumen and intestinal tracts of livestock animals (Seo et al., 2010). Commercial DFM are used in the dairy industry to improve performance and health of lactating dairy cows. Numerous experiments have reported that DFM have positive effects on digestion rate, DMI, milk yield, milk composition, rumen pH stability, and feed efficiency in lactating dairy cows (Nocek and Kautz, 2006; Ferguson et al., 2010; Qiao et al., 2010). Most of this research was performed using lactic acid-producing bacteria, lactic acid-utilizing bacteria, yeast, or fungi as DFM (Nocek et al., 2003; Stein et al., 2006; Oetzel et al., 2007; Weiss et al., 2008). The potential mode of action of those DFM has been summarized comprehensively (Krehbiel et al., 2003; Seo et al., 2010). Bacillus DFM have been shown to alter rumen fermentation patterns (higher propionate) and therefore we hypothesize that cows fed DFMt would be able to better cope with a high-starch diet (Peng et al., 2012).

Spore-forming bacteria have greater resistance to stresses during production and storage processes (Hyronimus et al., 2000) and greater resistance to gastric and intestinal environmental conditions (Sanders et al., 2003; Hong et al., 2005). Bacillus species are most commonly examined in this category and have been utilized as probiotic supplements for humans and for a variety of animal species (Cutting, 2011). Bacillus species have the potential to produce antimicrobial compounds, have 
broad enzymatic capabilities (Mongkolthanaruk, 2012), and have shown potential benefits in immune modulation in ruminants (Sun et al., 2010; Novak et al., 2012). Reports have demonstrated that Bacillus species could increase yields of milk, FCM, and milk protein (Kritas et al., 2006; Qiao et al., 2010). These observations may be explained by increased production of VFA (Qiao et al., 2010) and strong cellulolytic activity (Seo et al., 2010). Ferguson et al. (2010) reported that feeding $B$. pumilus 8G-134 increased milk yield and milk fat for the first 22 wk postpartum. Although not reported, performance improvement may have been a result of altered rumen fermentation patterns, which enhanced overall energy supply from the digestive tract.

The rumen fermentation pattern is physiologically altered around parturition. The transition period is defined as the period from about 3 wk before parturition until 3 wk postpartum. During the transition period, the dairy cow undergoes tremendous metabolic adaptations (Bell, 1995). As peak milk yield increases, the transition period for dairy cows becomes much more challenging with most infectious diseases and metabolic disorders occurring during this time (Grummer et al., 1995; Drackley, 1999). Milk production increases faster than energy intake in the first few weeks postpartum; thus, most cows will incur negative energy balance.

Therefore, our hypothesis was that B. pumilus as a DFM may be beneficial to minimize the extent of negative energy balance during the transition period and decrease the risk of metabolic disorders, thus improving health and performance during the transition period through lactation. The objectives of this experiment were to evaluate (1) the effect of Bacillus pumilus 8G134 as a DFM supplement on DMI, milk production and composition, and feed conversion from prepartum to mid-lactation; and (2) the effect of the DFM on BCS and incidence of subclinical ketosis during the transition period.

\section{MATERIALS AND METHODS}

\section{Animal Care and Housing}

All experimental procedures were approved by the University of Illinois at Urbana-Champaign Institutional Animal Care and Use Committee. Forty-three multiparous Holstein cows were assigned to 1 of 2 treatments in a randomized complete block design. Cows were blocked with regard to lactation number and previous lactation 305-d milk yield to ensure that these variables had minimal chance of influencing the outcome variables of the study. During the prepartum period, cows were housed in freestalls with individual Calan feed gates (American Calan Inc., Northwood,
$\mathrm{NH})$. Approximately $2 \mathrm{~d}$ before expected parturition, cows were moved to individual maternity pens in the same barn until parturition. After parturition, cows were housed in tiestalls with mangers designed for measurement of feed intake. Cows were milked 3 times daily. During the experimental period, cows were fed for ad libitum intake. Diets (pre- and postpartum) were formulated to meet or exceed cows' requirements according to NRC (2001) and were delivered once daily as a TMR.

\section{Treatments and Management}

Cows assigned to the DFM treatment (DFMt, $\mathrm{n}$ $=21$ ) received $5.0 \times 10^{9} \mathrm{cfu} / \mathrm{cow}$ of Bacillus pumilus 8G-134 DFM (DuPont Nutrition and Health, Waukesha, WI) in $28 \mathrm{~g}$ of maltodextrin carrier, whereas cows assigned to the control treatment $(\mathbf{C O N}, \mathrm{n}=22)$ received $28 \mathrm{~g}$ of maltodextrin carrier alone as a placebo. Treatments were mixed with $0.45 \mathrm{~kg}$ of ground corn and top-dressed on the close-up or lactation TMR once daily for each cow. Treatments were applied from $21 \pm$ $1 \mathrm{~d}$ before expected calving date to $154 \mathrm{~d}$ after calving. Cows were randomly assigned to treatments and balanced for initial BW $(719 \pm 9.6 \mathrm{~kg}$ vs. $715 \pm 9.8$ $\mathrm{kg}$ for CON and DFMt, respectively), parity (2.53 \pm 0.4 vs. $2.03 \pm 0.3$ for CON and DFMt, respectively), and previous lactation (305-d) milk production (11,703 $\pm 543 \mathrm{~kg}$ vs. $11,389 \pm 473 \mathrm{~kg}$ for CON and DFMt, respectively).

\section{Sample Collection}

Feed ingredients and TMR samples were obtained weekly and analyzed for DM content (AOAC International, 1995; method 934.01) by drying for $24 \mathrm{~h}$ in a forced-air oven at $110^{\circ} \mathrm{C}$. The TMR was adjusted weekly for changes in DM content of ingredients. Samples of TMR were taken weekly and stored at $-20^{\circ} \mathrm{C}$ until submitted for analysis. Monthly composite samples were analyzed for contents of DM, CP, ADF, NDF, lignin, starch, fat, ash, $\mathrm{Ca}, \mathrm{P}, \mathrm{Mg}, \mathrm{K}, \mathrm{Na}, \mathrm{Fe}, \mathrm{Zn}, \mathrm{Cu}$, $\mathrm{Mn}, \mathrm{Mo}$, and S using wet chemistry methods (Dairy One, 2014). Values for relative feed value, $\mathrm{TDN}, \mathrm{NE}_{\mathrm{L}}$, $\mathrm{NE}_{\mathrm{M}}, \mathrm{NE}_{\mathrm{G}}, \mathrm{ME}$, and digestible energy were provided by the laboratory and were based on NRC (2001). Intake from each cow was measured and DMI was recorded daily. Feed conversion (FE) calculations were based on ECM, FCM, or milk yield along with DMI (Tyrrell and Reid, 1965).

Cows were milked 3 times daily at 0600, 1400, and $2100 \mathrm{~h}$. Milk weights were recorded daily and samples were obtained from 3 consecutive milkings weekly. Consecutive weekly samples were composited in proportion 
to milk yield at each sampling and preserved (800 Broad Spectrum Microtabs II; D\&F Control Systems Inc., San Ramon, CA). Composite milk samples were analyzed for fat, protein, lactose, MUN, TS, and SCC using mid-infrared procedures (AOAC International, 1995; method 972.16) at a commercial laboratory (Dairy Lab Services, Dubuque, IA).

Health disorders included retained placenta $(\mathbf{R P})$, displaced abomasum (DA), clinical ketosis (CK), clinical mastitis (MAST), and clinical metritis (MET). Retained placenta was defined as a placenta that failed to deliver completely more than $12 \mathrm{~h}$ after calf delivery; DA was diagnosed by a veterinarian; CK was diagnosed by urinalysis strip (Ketostix, Bayer Corp. Diagnostics Division, Elkhart, IN); MAST was diagnosed by altered milk composition confirmed by positive microbiological culture; and MET was defined as uterine discharge that was foul, purulent, and orange-brown in color. Fecal score (FS) and general appearance (GA) were recorded daily. Fecal scores were assigned on a 1 to 4 scale according to Krause et al. (2009), where 1 = runny: liquid consistency, splatters on impact, spreads readily; 2 = loose: may pile slightly and spreads and splatters moderately on impact and setting; $3=$ soft: firm but not hard, piles but spreads slightly on impact and settling; 4 = dry: hard, dry appearance, original form not distorted on impact and settling. General appearance was scored according to Krause et al. (2009), where 1 $=$ bright and alert, $2=$ depressed, and $3=$ reluctant to rise. Cows with FS $\leq 2$ were classified as experiencing transient digestive problems, whereas cows with FS $>2$ were classified as healthy. Cows with GA $\geq 2$ were classified as sick (altered), whereas cows with GA $<2$ were classified as healthy.

Body weight was measured and BCS was assigned in quarter-unit increments (Ferguson et al., 1994) for each cow weekly. More than one individual assigned BCS independently at each time of scoring throughout the experiment and the average score was used.

Blood samples were collected from the coccygeal vein or artery on d 5 and d 14 after calving. Betahydroxybutyrate was measured immediately after the collection with a commercial blood ketone monitoring system (Precision Xtra, Abbott Diabetes Care Inc., Alameda, CA). Cows that had blood BHBA concentrations higher than $1.2 \mathrm{mmol} / \mathrm{L}$ were classified as having subclinical ketosis (SCK).

Blood samples were collected into tubes (BD Vacutainer; Becton, Dickinson, and Co., Franklin Lakes, NJ) containing clot activator for serum. Serum samples were obtained by centrifugation at $1,300 \times g$ for $15 \mathrm{~min}$ and stored at $-20^{\circ} \mathrm{C}$ until analyzed. Serum samples were analyzed for NEFA, which was determined by enzymatic analysis [NEFA-HR(2), Wako Diagnostics, Rich- mond, VA]. Cows that had NEFA serum concentrations $>0.7 \mathrm{mEq} / \mathrm{L}$ were classified as high (HNEFA), whereas cows that had NEFA serum concentrations lower than $0.7 \mathrm{mEq} / \mathrm{L}$ were classified as low (LNEFA). Both BHBA and NEFA variables were dichotomized based on cut-off points previously established by Ospina et al. (2010) and Iwersen et al. (2009). The immunoglobulins $\operatorname{IgA}, \operatorname{IgG}$, and $\operatorname{IgM}$ were quantified in milk collected during the first week after calving and in serum collected on d 5 and 14 by ELISA (Bethyl Laboratories, Montgomery, TX) according to the manufacturer's protocol. Haptoglobin was quantified in serum samples by ELISA (ALPCO, Salem, NH) according to the manufacturer's protocol. Cows that had serum haptoglobin concentrations $<150 \mu \mathrm{g} / \mathrm{mL}$ were classified as negative, whereas those with concentrations $>150 \mu \mathrm{g} / \mathrm{mL}$ were classified as positive, according to cut-off points previously established (Huzzey et al., 2009; Eckersall and Bell, 2010).

\section{Statistical Analyses}

The data were analyzed using SAS (v 9.3; SAS Institute Inc., Cary, NC). The MIXED models procedure was used for the outcomes of interest DMI, BW, BCS, milk parameters, and composed variables (e.g., feed conversion), which were averaged weekly. The model contained the fixed effects of treatment, week, and the interaction of treatment by week. Initial measurements, before treatment administration, were used as covariates when analyzing the dependent variables BW and BCS. Variables were subjected to 5 covariance structures: compound symmetry, autoregressive order 1 , autoregressive heterogeneous order 1 , unstructured, and Toeplitz. The covariance structure that yielded the lowest corrected Akaike information criterion was used in the model (Littell et al., 1998). Cow was the experimental unit and considered as a random effect. Week was included in the model as a repeated measurement with cow as subject. All performance variables were analyzed as weekly averages. Least squares means were calculated and are presented with standard errors of means (SEM). Degrees of freedom were estimated by using the Kenward-Roger method in the model statement (Littell et al., 1998). Residual distribution was evaluated for normality and homoscedasticity.

Dry matter intake before and after calving, milk yield change from calving to $3 \mathrm{wk}$, blood BHBA, plasma NEFA, serum and milk IgA, IgM, and IgG, and serum haptoglobin concentrations were analyzed as continuous variables using the MIXED procedure. A multivariable logistic mixed model (GLIMMIX procedure) was used for the dichotomized variables (SCK, NEFA, RP, DA, CK, MET, MAST, FS, GA, and haptoglobin). 
Table 1. Ingredient composition of prepartum and postpartum diets (DM basis) fed to cows receiving control or direct-fed microbial treatment (DFMt) throughout the experimental period

\begin{tabular}{lcc}
\hline Ingredient, \% of DM & Prepartum & Postpartum \\
\hline Alfalfa hay & 1.81 & 3.11 \\
Grass hay & 7.01 & 6.84 \\
Corn silage & 32.7 & 31.25 \\
Alfalfa silage & 6.33 & 3.91 \\
Wet brewers grain & 5.11 & 8.52 \\
Cottonseed & - & 3.08 \\
Soy hulls & - & 3.55 \\
Dry ground corn grain & -29.5 & 30.4 \\
Grain mix & & 12.5 \\
\hline
\end{tabular}

${ }^{1}$ Prepartum grain mix was formulated for $15.0 \% \mathrm{CP}, 38.1 \% \mathrm{NDF}, 23.3 \%$ ADF, 3.1\% lignin, 2.5\% crude fat, and $-23.0 \mathrm{mEq} / 100 \mathrm{~g} \mathrm{DCAD}$, and it contained $52.3 \%$ ground corn, $12.3 \%$ soybean hulls, $9.0 \%$ soybean meal, 6.4\% Soy Chlor (West Central, Ralston, IA); $6.3 \%$ limestone, $3.9 \%$ magnesium sulfate, $2.9 \%$ ammonium chloride, $1.0 \%$ vitamin E, $1.8 \%$ blood meal, $1.2 \%$ molasses, $1.9 \%$ Soy Plus (West Central), and $<1 \%$ of each of the following: dicalcium phosphate, vitamin A, vitamin $\mathrm{D}$, magnesium oxide, and trace minerals.

${ }^{2}$ Postpartum grain mix was formulated for $43.8 \% \mathrm{CP}, 8.9 \% \mathrm{NDF}, 5.1 \%$ ADF, $0.3 \%$ lignin, $12.2 \%$ crude fat, and $42.0 \mathrm{mEq} / 100 \mathrm{~g} \mathrm{DCAD}$, and it contained $35.8 \%$ soybean meal, $21.2 \%$ Soy Plus (West Central); $12.6 \%$ Enertia (ADM Alliance Nutrition, Quincy, IL), 10.0\% limestone, $4.9 \%$ urea, $4.5 \%$ sodium bicarbonate, $2.8 \%$ dicalcium phosphate, $2.0 \%$ magnesium sulfate, $2.0 \%$ white salt, $1.9 \%$ blood meal, $1.3 \%$ vitamin $\mathrm{E}$, and $<1 \%$ of each of the following: calcium sulfate dehydrate, magnesium oxide, vitamin $\mathrm{A}$, vitamin $\mathrm{D}$, and trace minerals.

The odds ratio (OR) were computed and are presented. The model used for each variable is indicated in the results section for each outcome of interest. A log-transformation was used for the variables NEFA, SCC, and haptoglobin for better homogeneity of the distribution of residuals. Means shown in tables and graphs for these variables are back-transformed. Statistical significance was declared as $P$-value $<0.05$, and tendency declared as $P$-value $<0.10$. A tendency was declared for the treatment $\times$ time interaction when the $\mathrm{P}$-value was $<0.15$.

\section{RESULTS}

The ingredient composition of the diets fed to cows is detailed in Table 1, and the analyzed chemical composition is shown in Table 2. Results for performance outcome variables are shown in Table 3 . Body weight, BCS, SCC, and MUN were not affected $(P>0.19)$ by treatment, and no treatment $\times$ week interaction $(P$ $>0.23$ ) was observed (Figures 1, 2, and 3). Dry matter intake was not affected by DFM supplementation during prepartum or postpartum periods, although we observed an overall treatment $\times$ week tendency $(P=$ 0.10) for both periods.

Production of milk, milk fat, FCM, and ECM were not affected by DFM supplementation (Figures 4 and 5). However, the treatment $\times$ week interaction was
Table 2. Mean $( \pm \mathrm{SD})$ chemical composition (\% of DM unless otherwise noted) for diets fed throughout the experimental period

\begin{tabular}{|c|c|c|}
\hline Component & Prepartum $^{1}$ & Postpartum $^{2}$ \\
\hline DM, $\%$ & $44.4 \pm 1.1$ & $46.8 \pm 2.7$ \\
\hline $\mathrm{CP}$ & $15.3 \pm 0.2$ & $15.8 \pm 0.5$ \\
\hline $\mathrm{ADF}$ & $24.2 \pm 0.6$ & $24.6 \pm 2.1$ \\
\hline NDF & $36.4 \pm 1.2$ & $36.3 \pm 2.3$ \\
\hline Lignin & $3.57 \pm 0.19$ & $3.63 \pm 0.53$ \\
\hline NFC & $37.6 \pm 0.8$ & $37.8 \pm 2.0$ \\
\hline Starch & $30.2 \pm 3.9$ & $26.3 \pm 4.5$ \\
\hline Crude fat & $4.03 \pm 0.6$ & $4.61 \pm 0.5$ \\
\hline Ash & $8.73 \pm 1.56$ & $7.70 \pm 0.62$ \\
\hline TDN & $69.0 \pm 1.8$ & $70.9 \pm 2.5$ \\
\hline $\mathrm{NE}_{\mathrm{L}}, \mathrm{Mcal} / \mathrm{kg}$ of $\mathrm{DM}$ & $0.73 \pm 0.02$ & $0.75 \pm 0.03$ \\
\hline $\mathrm{Ca}$ & $1.26 \pm 0.41$ & $1.02 \pm 1.45$ \\
\hline $\mathrm{P}$ & $0.31 \pm 0.03$ & $0.32 \pm 0.03$ \\
\hline $\mathrm{Mg}$ & $0.38 \pm 0.10$ & $0.28 \pm 0.07$ \\
\hline $\mathrm{K}$ & $1.14 \pm 0.04$ & $1.11 \pm 0.16$ \\
\hline $\mathrm{Na}$ & $0.11 \pm 0.12$ & $0.23 \pm 0.08$ \\
\hline S & $0.32 \pm 0.09$ & $0.23 \pm 0.03$ \\
\hline $\mathrm{Cl}$ & $0.97 \pm 0.41$ & $0.46 \pm 0.22$ \\
\hline $\mathrm{Fe}, \mathrm{mg} / \mathrm{kg}$ & $464 \pm 139$ & $363 \pm 62$ \\
\hline $\mathrm{Zn}, \mathrm{mg} / \mathrm{kg}$ & $125 \pm 3.2$ & $88.4 \pm 19.1$ \\
\hline $\mathrm{Cu}, \mathrm{mg} / \mathrm{kg}$ & $19.7 \pm 1.0$ & $15.5 \pm 3.2$ \\
\hline $\mathrm{Mn}, \mathrm{mg} / \mathrm{kg}$ & $118 \pm 27.8$ & $91.3 \pm 16.2$ \\
\hline Mo, mg $/ \mathrm{kg}$ & $0.90 \pm 0.18$ & $0.91 \pm 0.14$ \\
\hline
\end{tabular}

${ }^{1} \mathrm{n}=8$.

${ }^{2} \mathrm{n}=13$.

statistically significant $(P<0.01)$ for all the aforementioned outcome variables. This interaction may have occurred because cows receiving DFMt numerically produced more milk from wk 1 to 4 and wk 9 to 10 . Cows that received CON and DFMt had similar $(49.9 \%$ vs. $53.0 \% ; P>0.90)$ milk yield increases from wk 1 to 3 (Table 3). Additionally, cows receiving CON had higher DMI from wk 15 through wk 22 after calving than cows receiving DFMt.

Milk fat percentage was not affected by treatment but there was a tendency $(P<0.12)$ for a treatment $\times$ week interaction. Cows that received DFMt had numerically higher milk fat percentage from wk 5 to the end of the experiment compared with CON. Cows that received DFMt produced milk with 0.07 percentage units less $(P<0.07)$ lactose content compared with cows that received CON. On the other hand, milk lactose yield was not affected by DFM supplementation (Table 3).

Milk production efficiencies (calculated based on FCM and ECM) tended to be higher $(P<0.07)$ - by $0.1 \mathrm{~kg}$ of milk per kilogram of DMI-in cows that received DFMt compared with cows that received CON. We observed no treatment effect on FE based solely on milk yield. No treatment $\times$ week interaction was observed on any FE outcome variable.

We detected a day relative to calving effect for serum NEFA concentration as a continuous outcome variable but not a treatment effect (Table 4). At d 14 there was a tendency $(P=0.07)$ for cows receiving CON to 


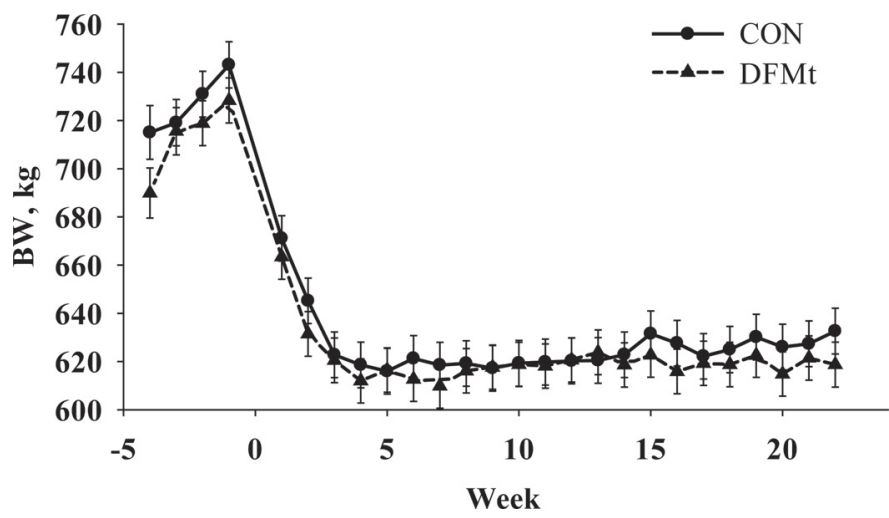

Figure 1. Least squares means and SEM for BW of cows receiving control (CON; $\mathrm{n}=22$ ) or direct-fed microbial (DFMt; $\mathrm{n}=21$ ) from wk -3 to 22 relative to calving. Treatment: $P=0.51$, week: $P<0.01$, and treatment $\times$ week: $P=0.75$.

have greater odds $(\mathrm{OR}=3.21)$ of being classified as HNEFA (serum NEFA concentration as a dichotomized outcome variable) when compared with DFMt cows. At d 5 , we observed a tendency $(P=0.06)$ for cows receiving $\mathrm{CON}$ to have greater odds $(\mathrm{OR}=3.85)$ of being classified as SCK compared with DFMt cows (Table 5).

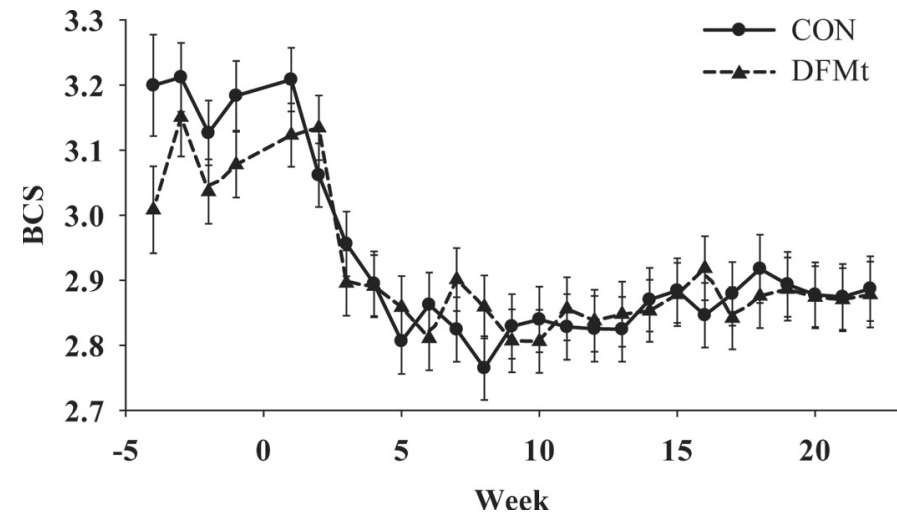

Figure 2. Least squares means and SEM for BCS of cows receiving control (CON; $\mathrm{n}=22$ ) or direct-fed microbial (DFMt; $\mathrm{n}=21$ ) from wk -3 to 22 relative to calving. Treatment: $P=0.70$, week: $P<0.01$, and treatment $\times$ week: $P=0.48$.

Blood haptoglobin concentrations did not differ $(P>$ 0.18 ) between treatments on either $\mathrm{d} 5$ or $\mathrm{d} 14$. There was a tendency $(P=0.09)$ for cows receiving CON to have greater odds $(\mathrm{OR}=3.55)$ of being classified as positive when compared with DFMt cows at d 14 after calving (Table 5).

Table 3. Least squares means and associated SEM for DMI, BW, BCS, and milk parameters response of Holstein cows top-dressed with Bacillus pumilus 8G-134 (DFMt) or placebo (CON) from wk 3 before calving through wk 22 after calving

\begin{tabular}{|c|c|c|c|c|c|c|}
\hline \multirow[b]{2}{*}{ Variable } & \multicolumn{2}{|c|}{ Treatment (Trt) } & \multirow[b]{2}{*}{ SEM } & \multicolumn{3}{|c|}{$P$-value } \\
\hline & $\mathrm{CON}$ & DFMt & & Trt & Week & Trt $\times$ Week \\
\hline \multicolumn{7}{|l|}{ Overall } \\
\hline DMI, kg/d & 20.6 & 20.0 & 0.49 & 0.35 & $<0.01$ & 0.10 \\
\hline $\mathrm{BW}, \mathrm{kg}$ & 642 & 635 & 8.04 & 0.51 & $<0.01$ & 0.75 \\
\hline BCS (1 to 5 scale) & 2.93 & 2.92 & 0.02 & 0.70 & $<0.01$ & 0.48 \\
\hline \multicolumn{7}{|l|}{ Prepartum } \\
\hline DMI, kg/d & 12.6 & 11.9 & 0.58 & 0.62 & $<0.06$ & 0.13 \\
\hline $\mathrm{BW}, \mathrm{kg}$ & 722 & 712 & 5.51 & 0.19 & $<0.01$ & 0.23 \\
\hline BCS (1 to 5 scale) & 3.13 & 3.11 & 0.04 & 0.71 & 0.44 & 0.95 \\
\hline \multicolumn{7}{|l|}{ Postpartum } \\
\hline DMI, kg/d & 21.9 & 21.3 & 0.54 & 0.44 & $<0.01$ & 0.09 \\
\hline $\mathrm{BW}, \mathrm{kg}$ & 628 & 620 & 8.65 & 0.53 & $<0.01$ & 0.75 \\
\hline BCS (1 to 5 scale) & 2.89 & 2.88 & 0.02 & 0.76 & $<0.01$ & 0.48 \\
\hline Milk yield, $\mathrm{kg} / \mathrm{d}$ & 41.6 & 42.2 & 0.88 & 0.61 & $<0.01$ & $<0.01$ \\
\hline Milk yield change from wk 1 to $3, \%$ & 49.9 & 53.0 & 16.8 & 0.90 & - & - \\
\hline Feed conversion (ECM:DMI) & 1.92 & 2.02 & 0.04 & 0.06 & $<0.01$ & 0.87 \\
\hline Feed conversion (FCM:DMI) & 1.98 & 2.09 & 0.05 & 0.07 & $<0.01$ & 0.81 \\
\hline Feed conversion (yield:DMI) & 2.00 & 2.05 & 0.05 & 0.42 & $<0.01$ & 0.32 \\
\hline $3.5 \% \mathrm{FCM},{ }^{1} \mathrm{~kg} / \mathrm{d}$ & 41.3 & 42.4 & 0.87 & 0.40 & $<0.01$ & $<0.01$ \\
\hline $\mathrm{ECM},{ }^{2} \mathrm{~kg} / \mathrm{d}$ & 40.1 & 40.9 & 0.86 & 0.46 & $<0.01$ & $<0.01$ \\
\hline Fat, $\%$ & 3.51 & 3.58 & 0.61 & 0.42 & $<0.01$ & 0.12 \\
\hline Fat, $\mathrm{kg} / \mathrm{d}$ & 1.45 & 1.50 & 0.03 & 0.27 & $<0.01$ & $<0.01$ \\
\hline Protein, \% & 2.76 & 2.77 & 0.03 & 0.93 & $<0.01$ & 0.32 \\
\hline Protein, kg/d & 1.14 & 1.16 & 0.03 & 0.63 & $<0.01$ & $<0.01$ \\
\hline Lactose, \% & 4.78 & 4.71 & 0.03 & 0.07 & $<0.01$ & 0.89 \\
\hline Lactose, $\mathrm{kg} / \mathrm{d}$ & 2.00 & 1.99 & 0.05 & 0.99 & $<0.01$ & 0.02 \\
\hline $\mathrm{SCC}, \times 1,000 / \mathrm{mL}$ & 153 & 239 & 73.8 & 0.30 & $<0.01$ & 0.81 \\
\hline MUN, mg/dL & 16.8 & 16.4 & 0.50 & 0.57 & $<0.01$ & 0.74 \\
\hline
\end{tabular}

${ }^{1} \mathrm{FCM}=[(0.4255 \times$ milk yield $)+(16.425 \times$ milk fat yield $)]$.

${ }^{2} \mathrm{ECM}=[(12.82 \times$ milk fat yield $)+(7.13 \times$ milk protein yield $)+(0.323 \times$ milk yield $)]$. 


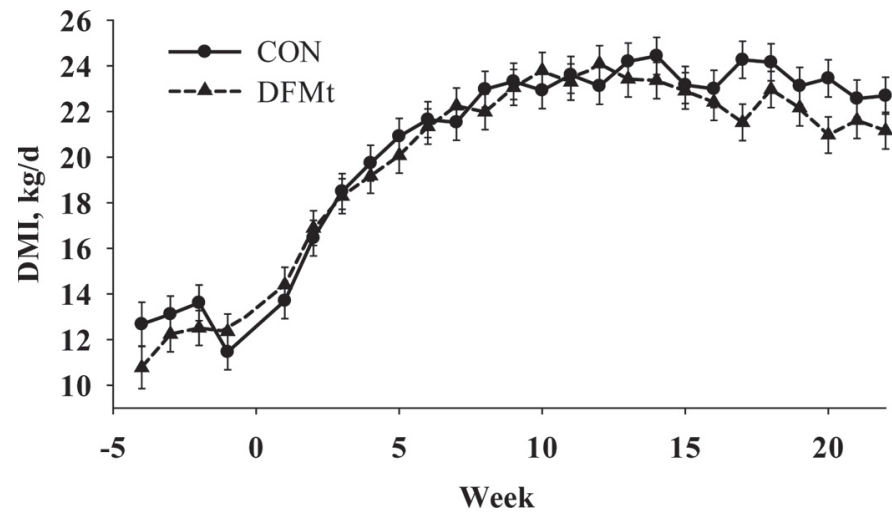

Figure 3. Least squares means and SEM for DMI of cows receiving control (CON; $\mathrm{n}=22$ ) or direct-fed microbial (DFMt; $\mathrm{n}=21$ ) from wk -3 to 22 relative to calving. Treatment: $P=0.35$, week: $P<0.01$, and treatment $\times$ week: $P=0.10$. Treatment CON resulted in higher $(P<0.01)$ DMI in wk 17 and 20 of lactation than DFMt.

Concentrations of $\operatorname{IgG}$ and IgM in milk or serum samples did not differ $(P>0.25)$ between treatments. Milk concentrations of IgA were higher $(P=0.03)$ during wk 1 for DFMt cows compared with $\mathrm{CON}$ cows; however, there was no overall difference $(P=0.42)$ in serum $\operatorname{Ig} \mathrm{A}$ concentrations between treatments. All measured health occurrences are shown in Table 5 . When analyzed for FS $\leq 2$ frequency, cows receiving CON tended $(P=0.08)$ to have higher probability for FS $\leq 2$ compared with DFMt cows (Table 5 ).

\section{DISCUSSION}

The aim of this study was to determine the efficacy of DFMt in improving the transition from late pregnancy to lactation and, as a result, improve produc-

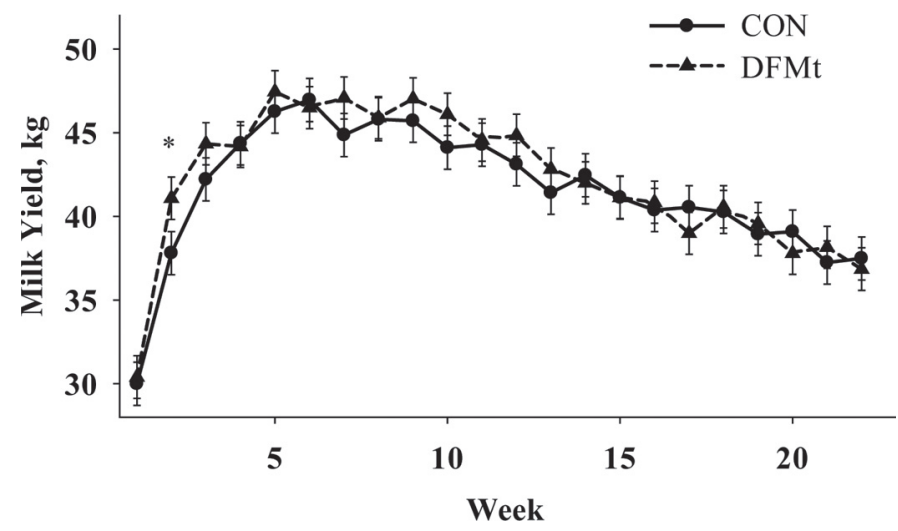

Figure 4. Least squares means and SEM for milk yield of cows receiving control $(\mathrm{CON} ; \mathrm{n}=22)$ or direct-fed microbial (DFMt; $\mathrm{n}=$ 21) from wk -3 to 22 relative to calving. Treatment: $P=0.61$, week: $P$ $<0.01$, and treatment $\times$ week: $P<0.01$. Treatment DFMt resulted in higher $(P<0.05)$ milk yield in wk 2 of lactation than CON (marked by an asterisk, $*)$.

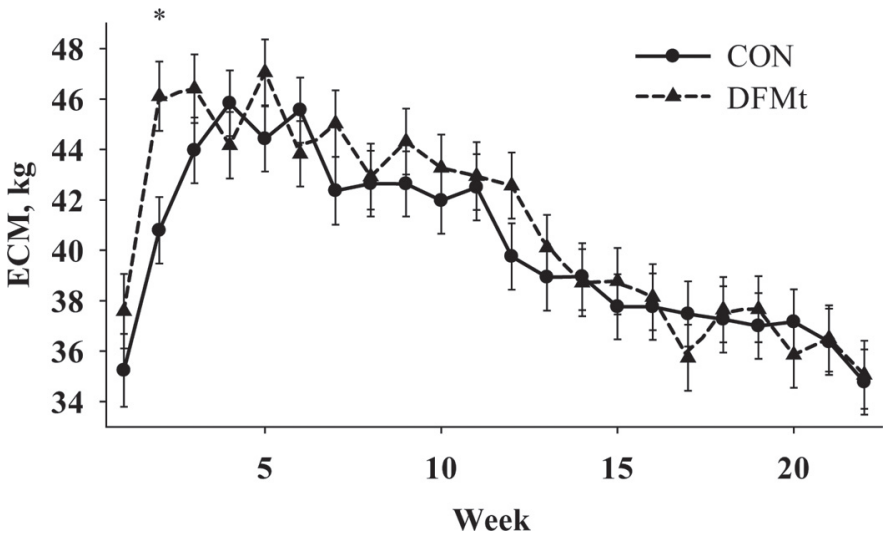

Figure 5. Least squares means and SEM of ECM for cows receiving control $(\mathrm{CON} ; \mathrm{n}=22)$ or direct-fed microbial (DFMt; $\mathrm{n}=21$ ) from wk -3 to 22 relative to calving. Treatment: $P=0.46$, week: $P<$ 0.01 , and treatment $\times$ week: $P<0.01$. Treatment DFMt resulted in higher $(P<0.01)$ ECM in wk 2 of lactation than CON (marked by an asterisk, $\left.{ }^{*}\right)$.

tive efficiency during lactation. We postulated that the Bacillus DFMt might affect the rumen or intestinal microbiota or modulate the immune system, thereby affecting DMI, nutrient supply, metabolic responses, and productive efficiency.

The DMI interaction prepartum may be explained by the fact that DMI of cows that received DFMt only decreased $0.15 \mathrm{~kg} / \mathrm{d}$ from $\mathrm{wk}-2$ to -1 relative to calving, whereas cows that received CON decreased 2.16 $\mathrm{kg} / \mathrm{d}$. However, DMI increased faster for CON cows than for DFMt cows after calving (Table 3). Cows that received DFMt numerically seemed to have higher DMI in the last week before calving than cows that received $\mathrm{CON}$, which may have been pivotal for a more sound transition that consequently supported higher milk production during early lactation.

Lactose production was not different between DFMt and $\mathrm{CON}$, even though the lactose percentage tended to be higher in CON than in DFMt. Milk yield was numerically higher for cows receiving DFMt compared with cows receiving $\mathrm{CON}$; therefore, the percentage difference was offset by the difference in milk production.

Cows that received DFMt had higher FE using either FCM or ECM but not milk as the variable of interest (Figure 6). This finding may indicate that cows that received DFMt more efficiently converted feed into milk components during the first 22 wk of lactation (Figure 6). The extra milk output in relation to DMI (which did not differ between treatments) came with no apparent penalty from the perspective of body tissue mobilization as we assessed based on the lack of treatment differences on BW and BCS. Indeed, cows that received CON showed signs of excessive adipose tissue mobilization as indicated by higher concentra- 
Table 4. Least squares means of blood and milk metabolites at 5 and 14 d relative to calving from Holstein cows top-dressed with Bacillus pumilus 8G-134 (DFMt) or placebo (CON) from wk 3 before calving through wk 22 after calving

\begin{tabular}{|c|c|c|c|c|c|c|}
\hline \multirow[b]{2}{*}{ Variable } & \multicolumn{2}{|c|}{ Treatment (Trt) } & \multirow[b]{2}{*}{ SEM } & \multicolumn{3}{|c|}{$P$-value } \\
\hline & $\mathrm{CON}$ & DFMt & & Trt & $\mathrm{DRC}^{1}$ & $\mathrm{DRC} \times \operatorname{Trt}$ \\
\hline \multicolumn{7}{|l|}{ Blood $^{2}$} \\
\hline NEFA, mEq/L & 0.78 & 0.69 & 0.06 & 0.60 & 0.07 & 0.67 \\
\hline $\mathrm{BHBA}, \mathrm{mmol} / \mathrm{L}$ & 1.56 & 1.59 & 0.22 & 0.93 & 0.54 & 0.26 \\
\hline $\operatorname{Ig} \mathrm{A}, \mu \mathrm{g} / \mathrm{mL}$ & 98.9 & 110 & 10.2 & 0.42 & 0.92 & 0.34 \\
\hline $\mathrm{IgG}, \mu \mathrm{g} / \mathrm{mL}$ & 17,159 & 15,805 & 1,335 & 0.46 & 0.74 & 0.31 \\
\hline $\mathrm{IgM}, \mu \mathrm{g} / \mathrm{mL}$ & 89.8 & 108 & 11.4 & 0.25 & 0.39 & 0.94 \\
\hline Haptoglobin, $\mu \mathrm{g} / \mathrm{mL}$ & 1.87 & 0.72 & 0.57 & 0.15 & 0.04 & 0.46 \\
\hline \multicolumn{7}{|l|}{ Milk $^{3}$} \\
\hline $\operatorname{IgA}, \mu \mathrm{g} / \mathrm{mL}$ & 478 & 584 & 35.0 & 0.03 & - & - \\
\hline $\mathrm{IgG}, \mu \mathrm{g} / \mathrm{mL}$ & 514 & 512 & 65.0 & 0.99 & - & - \\
\hline $\mathrm{IgM}, \mu \mathrm{g} / \mathrm{mL}$ & 6.94 & 8.02 & 0.90 & 0.40 & - & - \\
\hline
\end{tabular}

${ }^{1}$ Days relative to calving (5 and 14$)$.

${ }^{2}$ Samples collected d 5 and 14 relative to calving from 42 cows $(\mathrm{CON}, \mathrm{n}=21$; DFMt, $\mathrm{n}=21)$.

${ }^{3}$ Samples collected in the first week of lactation from 40 cows $(\mathrm{CON}, \mathrm{n}=20$; DFMt, $\mathrm{n}=20)$.

tions of BHBA and NEFA after calving compared with DFMt cows (Table 5). Although, as a result, CON cows would be expected to have greater milk fat content early postpartum, we were not able to detect a milk fat percentage difference between treatments. However, milk fat yield $(\mathrm{kg})$ displayed an interesting treatment by week interaction. Cows receiving DFMt were able to produce considerably greater fat yield in the beginning

Table 5. Multivariable logistic mixed models of blood metabolites and health occurrences from Holstein cows top-dressed with Bacillus pumilus 8G-134 (DFMt) or placebo (CON) from wk 3 before calving through wk 22 after calving

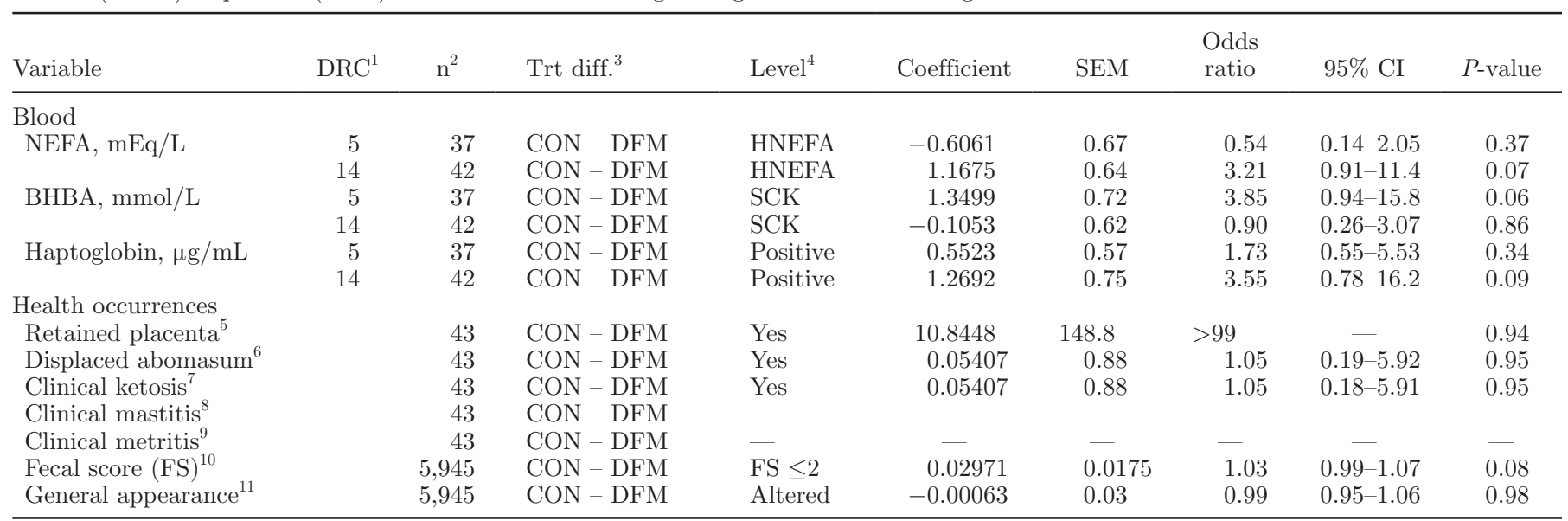

${ }^{1}$ Days relative to calving.

${ }^{2}$ Observations used from both CON and DFMt treatments.

${ }^{3}$ Differences of treatment (Trt) least squares means.

${ }^{4}$ The NEFA classes were based on serum concentrations $\leq 0.7 \mathrm{mEq} / \mathrm{L}$ (low; referent) and $>0.7 \mathrm{mEq} / \mathrm{L}$ (high, HNEFA). The BHBA classes were based on blood concentrations $\leq 1.2 \mathrm{mmol} / \mathrm{L}$ (subclinical ketosis, $\mathrm{SCK}=$ no; referent) and high $>1.2 \mathrm{mmol} / \mathrm{L}$ (SCK = yes). Haptoglobin classes were based on serum concentrations $\leq 150 \mu \mathrm{g} / \mathrm{mL}$ (haptoglobin = negative, referent) and positive $>150 \mu \mathrm{g} / \mathrm{mL}$ (haptoglobin $=$ positive).

${ }^{5} \mathrm{CON}(\mathrm{n}=21$; yes $=2$, and no $=19)$ and $\operatorname{DFMt}(\mathrm{n}=22$; yes $=0$, and no $=22)$.

${ }^{6} \operatorname{CON}(\mathrm{n}=21 ;$ yes $=3$, and no $=18)$ and $\operatorname{DFMt}(\mathrm{n}=22 ;$ yes $=3$, and no $=19)$.

${ }^{7} \mathrm{CON}(\mathrm{n}=21 ;$ yes $=3$, and no $=18)$ and $\operatorname{DFMt}(\mathrm{n}=22 ;$ yes $=3$, and no $=19)$.

${ }^{8} \mathrm{CON}(\mathrm{n}=21 ;$ yes $=0$, and no $=21)$ and $\operatorname{DFMt}(\mathrm{n}=22 ;$ yes $=0$, and no $=22)$.

${ }^{9} \mathrm{CON}(\mathrm{n}=21$; yes $=0$, and no $=21)$ and DFMt $(\mathrm{n}=22$; yes $=0$, and no $=22)$.

${ }^{10}$ Where $1=$ runny; $2=$ loose; $3=$ soft; $4=$ dry; CON $(\mathrm{n}=2,920 ; \mathrm{FS} \leq 2=123$, and healthy $=2,797)$ and DFMt $(\mathrm{n}=3,024 ; \mathrm{FS} \leq 2$, and healthy $=2,951)$. No time $(P=1.00)$ or treatment by time $(P=1.00)$ effect was observed.

${ }^{11}$ Where $1=$ bright and alert; $2=$ depressed; $3=$ reluctant to rise. CON $(\mathrm{n}=2,920$; altered $=27$, and healthy $=2,893)$ and DFMt $(\mathrm{n}=3,024$; altered $=27$, and healthy $=2,997)$. No time $(P=1.00)$ or treatment by time $(P=1.00)$ effect was observed. 


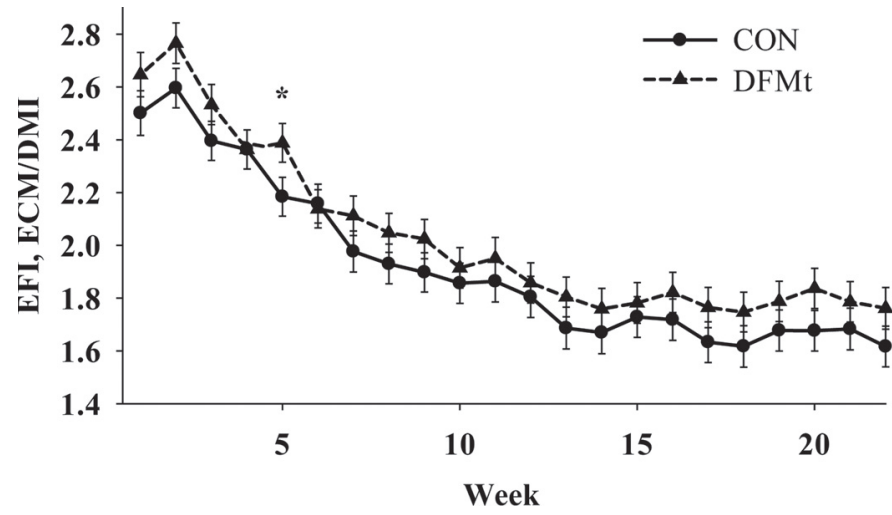

Figure 6. Least squares means and SEM for feed conversion (EFI), represented as ECM $(\mathrm{kg}) / \mathrm{DMI}(\mathrm{kg})$ by cows receiving control $(\mathrm{CON}$ $\mathrm{n}=22$ ) or direct-fed microbial (DFMt; $\mathrm{n}=21$ ) from $\mathrm{wk}-3$ to 22 relative to calving. Treatment: $P=0.06$, week: $P<0.01$, and treatment $\times$ week: $P<0.87$. Treatment DFMt resulted in higher $(P=0.02) \mathrm{EFI}$ in wk 5 of lactation than CON (marked by an asterisk, ${ }^{*}$ ).

of lactation (wk 2) compared with cows receiving CON. The difference in milk fat yield likely contributed to the increased FE measured as FCM:DMI or ECM:DMI, but not milk:DMI.

The aforementioned findings partially agree with those of Ferguson et al. (2010), where the authors concluded that the Bacillus treatments (BAC; Bacillus pumilus $8 \mathrm{G}-134$ offered at $5 \times 10^{9}$ and $1 \times 10^{10} \mathrm{cfu} / \mathrm{d}$ ) significantly increased milk volume and milk fat content compared with the control treatment and increased milk volume compared with the Lactobacillus treatment (LAC). Those authors suggested that cows on $\mathrm{BAC}$ treatments could have mobilized more body tissue reserves than the control cows to produce more milk and eat less than expected, but serum NEFA, glucose, and BHBA concentrations suggested that those cows were in similar energy status as control cows. Additionally, the authors found that BW and BCS were similar for the BAC groups relative to the control group and suggested that cows receiving $\mathrm{BAC}$ did not mobilize more body tissue to produce the additional milk volume. Such findings would invoke a mechanism either of improving nutrient capture from feed consumed or decreasing maintenance (e.g., immune response) requirements.

In contrast to the experiment of Ferguson et al. (2010), we did not find statistical treatment differences for milk yield. One of the reasons for this could be that cows on their experiment were milked 2 times a day and produced (or had lower potential for milk production) less milk overall compared with cows in our experiment that were milked 3 times a day $(\sim 35 \mathrm{~kg}$ vs. $\sim 41 \mathrm{~kg})$.

A relationship between occurrence of postpartum metabolic disorders and blood NEFA and BHBA con- centrations has been proposed (Hegardt, 1999; Drackley et al., 2001). Ospina et al. (2010) collected blood samples from 1,672 cows from 60 different herds in the United States. Samples were collected weekly starting from 2 wk before calving until 2 wk after calving. By measuring serum concentrations of NEFA and BHBA postpartum, the authors concluded that cows above the identified cut-off points $(0.7 \mathrm{mEq} / \mathrm{L}$ for NEFA and 1.2 $\mathrm{mmol} / \mathrm{L}$ for BHBA) (1) were $1.7 \%$ more at risk for disease occurrence (CK and DA); (2) had 0.8\% lower pregnancy rate; and (3) produced $332 \mathrm{~kg}$ less $305-\mathrm{d}$ mature-equivalent milk than herdmates below the cutoff points. The current experiment resulted in relatively higher NEFA and BHBA concentrations compared with other experiments performed peripartum (Douglas et al., 2006; Janovick et al., 2011), which might be a result of the high starch content in the diet for the prepartum period in the present research, as designed (Cardoso et al., 2013). Bacillus DFM have been shown to increase rumen fermentation pattern (higher propionate) and therefore we hypothesize that cows fed DFMt would be able to better cope with a high-starch diet (Peng et al., 2012).

Immunoglobulin $\mathrm{G}$ is the most abundant immunoglobulin in both serum and milk of dairy cows (Stelwagen et al., 2009). The majority of milk $\operatorname{IgG}$ is produced by plasma cells systemically and is extracted from blood by the mammary gland to be secreted in milk. In contrast to IgG, the majority of milk IgM and $\operatorname{Ig} \mathrm{A}$ is produced locally by plasma cells in mammary tissue (Hurley and Theil, 2011). These IgM- and IgAproducing cells originate in gut-associated lymphoid tissue and migrate to the mammary gland. This difference in synthesis could explain why DFMt was able to increase milk concentrations of IgA but not IgG. Although there is no direct contact between DFM and mammary tissue, DFM do interact with the mucosal immune system in the gastrointestinal tract, which may have influenced the activity of plasma cells before their migration to the mammary gland.

Immunoglobulin A has protective effects that would aid in the defense against pathogens in the mammary gland (Larson et al., 1980). Immunoglobulin A, normally found at mucosal sites, binds to bacterial cells and prevents their adhesion to epithelial cells. The additional immune defense provided by DFMt could explain the difference in haptoglobin concentrations between DFMt and CON cows. In a healthy cow, serum haptoglobin concentrations have been shown to be $<40 \mu \mathrm{g} /$ mL (Huzzey et al., 2009, 2011). In response to disease such as mastitis or endometritis, haptoglobin serum concentrations can increase 100-fold or more (Eckersall and Bell, 2010). An increase in IgA in the mammary gland may provide greater protection against infection, 
reducing the incidence of disease and elevated haptoglobin concentrations. Elevated milk immunoglobulins also have the added benefit of boosting neonatal calf health through passive transfer of immunity. In particular, $\operatorname{IgA}$ provides mucosal protection in the calf gastrointestinal tract, aiding in the development of a healthy immune system and gut microbiota (Salmon, 1999; Hurley and Theil, 2011).

There have been several other reports of Bacillus DFM influencing immunity. Sun et al. (2010) reported a change in immunoglobulins associated with a Bacillus DFM fed to neonatal calves. In contrast to our study, they observed elevated levels of serum IgG in DFMtreated calves and did not find a change in IgA or IgM level. A study by Novak et al. (2012) found that administration of a Bacillus DFM to dairy calves resulted in altered immune cell populations and an improvement in immune development. The immune-modulating effect of Bacillus is also evident in nonruminants. Lee et al. (2010) found that a Bacillus DFM affected lymphocyte populations, cytokine expression, and acute phase proteins in chickens.

Further potential mechanisms to explain the DFMt mode of action certainly encompass the rumen microbiome and dynamics. Ferguson et al. (2010) reported a numerically higher proportion of acetate in rumen fluid compared with propionate, butyrate, lactate, and isobutyrate for Bacillus pumilus compared with control and Lactobacillus treatments. Another interesting finding from that experiment was that the rumen fluid from cows fed Bacillus pumilus had a numerically lower concentration of rumen ammonia than either control or Lactobacillus treatment.

Reduction (by competition, inhibition, or phages) of hyper-ammonia-producing ruminal bacteria (HAB) in the rumen could be one potential mechanism for lowered rumen ammonia. Coculture experiments with $\mathrm{HAB}$ found that washed mixed-rumen bacteria (MRB) from cattle fed grain were able to decrease ammonia production from $\mathrm{HAB}$, but MRB from cattle fed hay did not affect HAB (Rychlik and Russell, 2000). Those authors used autoclaved MRB and did not observe HAB inhibition. Some examples of HAB are Clostridium spp., Peptostreptococcus anaerobius, Clostridium aminophilum, and Fusobacterium necrophorum (Attwood et al., 1998). Clostridial organisms are part of the normal flora of dairy cattle and only become problematic with uncontrolled multiplication in situations of injury, changes in diet or management, stress, or parasitism that favor clostridial organism growth, which may then result in production of potent toxins (e.g., enterotoxemia). Specifically, Clostridium perfringens has been incriminated in enteric syndromes affecting both calves and cows (Lebrun et al., 2010). Interestingly, in the current study, cows that received DFMt had higher FS (i.e., firmer feces) compared with cows that received CON. Ionophores (e.g., monensin) can inhibit HAB population in the rumen, but ionophores were not included in our experimental diets. The DFMt could also have had a direct effect in the rumen and hindgut of cows (Seo et al., 2010). Although speculative, our findings are consistent with both a local effect of greater IgA production in the gut and alterations in $\mathrm{HAB}$ populations in the rumen when cows are supplemented with DFMt.

\section{CONCLUSIONS}

Although the exact mode of action of the DFMt remains unknown, the outcomes from the present study are complementary and consistent with the fact that cows receiving DFMt had a more metabolically sound transition period and higher feed conversion in early lactation compared with cows receiving CON. Cows receiving CON seemed to have higher DMI by the end of the experimental period, which contributed to the increased feed conversion for cows receiving DFMt. Additionally, DFMt appeared to improve immunity in the mammary gland and reduce the incidence of elevated haptoglobin. Administration of DFMt has the potential to improve milk production efficiency and overall health during the transition period.

\section{REFERENCES}

AOAC International. 1995. Official Methods of Analysis. 16th ed. Vol. 2. AOAC International, Arlington, VA.

Attwood, G. T., A. V. Klieve, D. Ouwerkerk, and B. K. C. Patel. 1998. Ammonia-hyperproducing bacteria from New Zealand ruminants. Appl. Environ. Microbiol. 64:1796-1804.

Bell, A. W. 1995. Regulation of organic nutrient metabolism during transition from late pregnancy to early lactation. J. Anim. Sci. 73:2804-2819.

Cardoso, F. C., S. J. LeBlanc, M. R. Murphy, and J. K. Drackley. 2013. Prepartum nutritional strategy affects reproductive performance in dairy cows. J. Dairy Sci. 96:5859-5871.

Cutting, S. M. 2011. Bacillus probiotics. Food Microbiol. 28:214-220.

Dairy One. 2014. Analytical Procedures - Forage. Dairy One, Ithaca, NY. Accessed May 4, 2015. http://dairyone.com/wp-content/ uploads/2014/02/Forage-Lab-Analytical-Procedures.pdf.

Douglas, G. N., T. R. Overton, H. G. Bateman, H. M. Dann, and J. K. Drackley. 2006. Prepartal plane of nutrition, regardless of dietary energy source, affects periparturient metabolism and dry matter intake in Holstein cows. J. Dairy Sci. 89:2141-2157.

Drackley, J. K. 1999. Biology of dairy cows during the transition period: The final frontier. J. Dairy Sci. 82:2259-2273.

Drackley, J. K., T. R. Overton, and G. N. Douglas. 2001. Adaptations of glucose and long-chain fatty acid metabolism in liver of dairy cows during the periparturient period. J. Dairy Sci. 84(E. Suppl.):E100-E112.

Eckersall, P. D., and R. Bell. 2010. Acute phase protein: Biomarkers of infection and inflammation in veterinary medicine. Vet. J. $185: 23-27$. 
Ferguson, J. D., D. T. Galligan, and N. Thomsen. 1994. Principal descriptors of body condition score in Holstein cows. J. Dairy Sci. 77:2695-2703.

Ferguson, J. D., Z. Wu, D. W. Remsberg, and K. Mertz. 2010. The influence of Bacillus pumilus $8 \mathrm{G}-134$ on milk production of dairy cows in early lactation. J. Dairy Sci. 93(Suppl. 1):871. (Abstr.)

Grummer, R. R., P. C. Hoffman, M. L. Luck, and S. J. Bertics. 1995. Effect of prepartum and postpartum dietary energy on growth and lactation of primiparous cows. J. Dairy Sci. 78:172-180.

Hegardt, F. G. 1999. Mitochondrial 3-hydroxy-3 methylglutaryl-CoA synthase: A control enzyme in ketogenesis. Biochem. J. 338:569582

Hong, H. A., H. D. Le, and S. M. Cutting. 2005. The use of bacterial spore formers as probiotics. FEMS Microbiol. Rev. 29:813-835.

Hurley, W. L., and P. K. Theil. 2011. Perspectives on immunoglobulins in colostrums and milk. Nutrients 3:442-474.

Huzzey, J. M., T. F. Duffield, S. J. LeBlanc, D. M. Veira, D. M. Weary, and M. A. G. von Keyserlingk. 2009. Short communication: Haptoglobin as an early indicator of metritis. J. Dairy Sci. 92:621-625.

Huzzey, J. M., D. V. Nydam, R. J. Grant, and T. R. Overton. 2011. Associations of prepartum plasma cortisol, haptoglobin, fecal cortisol metabolites, and nonesterified fatty acids with postpartum health status in Holstein dairy cows. J. Dairy Sci. 94:5878-5889.

Hyronimus, B., C. Le Marrec, A. Hadj Sassi, and A. Deschamps. 2000 Acid and bile tolerance of spore-forming lactic acid bacteria. Int. J. Food Microbiol. 61:193-197.

Iwersen, M., U. Falkenberg, R. Voigtsberger, D. Forderung, and W. Heuwieser. 2009. Evaluation of an electronic cowside test to detect subclinical ketosis in dairy cows. J. Dairy Sci. 92:2618-2624.

Janovick, N. A., Y. R. Boisclair, and J. K. Drackley. 2011. Prepartum dietary energy intake affects metabolism and health during the periparturient period in primiparous and multiparous Holstein cows. J. Dairy Sci. 94:1385-1400.

Krause, K. M., D. V. Dhuyvetter, and G. R. Oetzel. 2009. Effect of a low-moisture buffer block on ruminal $\mathrm{pH}$ in lactating dairy cattle induced with subacute ruminal acidosis. J. Dairy Sci. 92:352-364.

Krehbiel, C. R., S. R. Rust, G. Zang, and S. E. Gilliland. 2003. Bacterial direct-fed microbials in ruminant diets: Performance response and mode of action. J. Anim. Sci. 81(E-Suppl.):E120-E132.

Kritas, S. K., A. Govaris, G. Christodoulopoulos, and A. R. Burriel. 2006. Effect of Bacillus licheniformis and Bacillus subtilis supplementation of ewe's feed on sheep milk production and young lamb mortality. J. Vet. Med. A Physiol. Pathol. Clin. Med. 53:170-173.

Larson, B. L., H. L. Heary Jr., and J. E. Devery. 1980. Immunoglobulin production and transport by the mammary gland. J. Dairy Sci. 63:665-671.

Lebrun, M., J. G. Mainil, and A. Linden. 2010. Cattle enterotoxaemia and Clostridium perfringens: Description, diagnosis and prophylaxis. Vet. Rec. 167:13-22.

Lee, K. W., S. H. Lee, H. S. Lillehoj, G. X. Li, S. I. Jang, U. S. Babu, M. S. Park, D. K. Kim, E. P. Lillehoj, A. P. Neumann, T. G. Rehberger, and G. R. Siragusa. 2010. Effects of direct-fed microbials on growth performance, gut morphometry, and immune characteristics in broiler chickens. Poult. Sci. 89:203-216.

Littell, R. C., P. R. Henry, and C. B. Ammerman. 1998. Statistical analysis of repeated measures data using SAS procedures. J. Anim. Sci. 76:1216-1231.

Mongkolthanaruk, W. 2012. Classification of Bacillus beneficial substances related to plants, humans and animals. J. Microbiol. Biotechnol. 22:1597-1604.
Nocek, J. E., and W. P. Kautz. 2006. Direct-fed microbial supplementation on ruminal digestion, health, and performance of pre- and postpartum dairy cattle. J. Dairy Sci. 89:260-266.

Nocek, J. E., W. P. Kautz, J. A. Z. Leedle, and E. Block. 2003. Directfed microbial supplementation on the performance of dairy cattle during the transition period. J. Dairy Sci. 86:331-335.

Novak, K. N., E. Davis, C. A. Wehnes, D. R. Shields, J. A. Coalson, A. H. Smith, and T. G. Rehberger. 2012. Effect of supplementation with an electrolyte containing a Bacillus-based direct-fed microbial on immune development in dairy calves. Res. Vet. Sci. 92:427-434.

NRC. 2001. Nutrient Requirements of Dairy Cattle. 7th rev. ed. Natl. Acad. Sci., Washington, DC

Oetzel, G. R., K. M. Emery, W. P. Kautz, and J. E. Nocek. 2007. Direct-fed microbial supplementation and health and performance of pre- and postpartum dairy cattle: A field trial. J. Dairy Sci. 90:2058-2068.

Ospina, P. A., D. V. Nydam, T. Stokol, and T. R. Overton. 2010. Evaluation of nonesterified fatty acids and $\beta$-hydroxybutyrate in transition dairy cattle in the northeastern United States: Critical thresholds for prediction of clinical diseases. J. Dairy Sci. 93:546-554.

Peng, H., J. Q. Wang, H. Y. Kang, S. H. Dong, P. Sun, D. P. Bu, and L. Y. Zhou. 2012. Effect of feeding Bacillus subtilis natto fermentation product on milk production and composition, blood metabolites and rumen fermentation in early lactation dairy cows. J. Anim. Physiol. Anim. Nutr. (Berl.) 96:506-512.

Qiao, G. H., A. S. Shan, N. Ma, Q. Q. Ma, and Z. W. Sun. 2010. Effect of supplemental Bacillus cultures on rumen fermentation and milk yield in Chinese Holstein cows. J. Anim. Physiol. Anim. Nutr. (Berl.) 94:429-436.

Rychlik, J. L., and J. B. Russell. 2000. Mathematical estimations of hyper-ammonia producing ruminal bacteria and evidence for bacterial antagonism that decreases ruminal ammonia production. FEMS Microbiol. Ecol. 32:121-128.

Salmon, H. 1999. The mammary gland and neonate mucosal immunity. Vet. Immunol. Immunopathol. 72:143-155.

Sanders, M. E., L. Morelli, and T. A. Tompkins. 2003. Sporeformers as human probiotics: Bacillus, Sporolactobacillus, and Brevibacillus. Compr. Rev. Food Sci. Food Safety 2:101-110.

Seo, J. K., S. W. Kim, M. H. Kim, S. D. Upadhaya, D. K. Kam, and J. K. Ha. 2010. Direct-fed microbials for ruminant animals. Asianaustralas. J. Anim. Sci. 23:1657-1667.

Stein, D. R., D. T. Allen, E. B. Perry, J. C. Bruner, K. W. Gates, T. G. Rehberger, K. Mertz, D. Jones, and L. J. Spicer. 2006. Effects of feeding propionibacteria to dairy cows on milk yield, milk components, and reproduction. J. Dairy Sci. 89:111-125.

Stelwagen, K., E. Carpenter, B. Haigh, A. Hodgkinson, and T. T. Wheeler. 2009. Immune components of bovine colostrum and milk. J. Anim. Sci. 87:3-9.

Sun, P., J. Q. Wang, and H. T. Zhang. 2010. Effects of Bacillus subtilis natto on performance and immune function of preweaning calves. J. Dairy Sci. 93:5851-5855.

Tyrrell, H. F., and J. T. Reid. 1965. Prediction of the energy value of cow's milk. J. Dairy Sci. 48:1215-1223.

Weiss, W. P., D. J. Wyatt, and T. R. McKelvey. 2008. Effect of feeding propionibacteria on milk production by early lactation dairy cows. J. Dairy Sci. 91:646-652. 